on human trypanosomiasis in north-eastern Rhodesia and Nyasaland, and on trypanosomiasis of domestic stock in north-eastern Rhodesia. The reports contain much valuable information concerning the habits and occurrence of the species of Glossina and other biting flies, the various types of trypanosomes (illustrated by photomicrographs) met with in the blood of diseased domestic animals, and other important points, and the question of prophylactic measures against trypanosomiasis is discussed both for human beings and animals.

In another memoir Messrs. Breinl and Nierenstein give an account of their biochemical and therapeutical studies on trypanosomiasis. After a detailed account of their " observations on experimental trypanosomiasis, the treatment of infections with different pathogenic trypanosomes, and the mechanism of the therapeutical action of various trypanocidal compounds," they raise the question, "When can an animal be considered to be cured?" No very definite answer is given, however, to this question, and it is concluded that "the general condition of experimental animals influences to a large extent the results obtained in therapeutical experiments." The memoir ends with a brief discussion on the comparative value of experiments on different laboratory animals.

The two remaining memoirs are by Prof. John Cardamatis, on sanitary measures and malaria epidemics of Athens, and by H. B. Day and Prof, A. R. Ferguson, on a form of splenomegaly, with hepatic cirrhosis, endemic in Egypt. Both memoirs are illustrated by photographs.

In the Annals of Tropical Medicine and Parasitology, vol. iv., part iv., are published two reports of the expedition of the Liverpool School of Tropical Medicine to Jamaica. The first of these reports is by Mr. Robert Newstead, on the ticks and other blood-sucking Arthropoda of Jamaica. The author gives most interesting bionomical notes, as well as systematic descriptions; of these pests, and suggests measures to be taken for the extermination of ticks. The most active enemies of ticks were found to be birds, especially the tinkling grackle (Quiscalus crassirostris), the parrot-billed blackbird (Crotophaga ani), and the domestic fowl. In the stomach of Crotophaga there were also found specimens of the "green stink-bug" (Loxa flavicollis), an observation of great bionomical interest, since this insect, though possessed of an odour which is " horribly offensive," has a protective green coloration. The second report is by Dr. W. T. Prout, on malaria. After discussing the nature and etiology of the disease and its occurrence in Jamaica, the author gives an account of anti-malarial measures and their effects in Jamaica and elsewhere, and suggests practical means for combating the disease.

\section{PRODUCTION AND UTILISATION OF} MOLASSES.

THE production of molasses is an important factor in the cane-sugar industry, and has received a good deal of attention in sugar-growing countries. Molasses constitute the thick mother liquor left after the sucrose has crystallised out, and, no matter what artifice be adopted, there is a point beyond which it seems impossible to obtain any more crystals, the sugar being held back by the foreign bodies present. Hertzfeld has shown that the formation of beet-sugar molasses is due to the mineral matter originally present in the juice, or added in the liming process, reacting with the sucrose to form noncrystallisable compounds. Prinsen Geerligs has proved that similar compounds are formed in working up cane sugar. The problem is complicated here by the presence of glucose, which reacts more readily with the mineral' substances than does sucrose. In this way is explained the definitely established fact that, the larger the proportion of glucose to mineral matter, the greater the recovery of sugar is likely to be. There appears also to be a physical factor involved; gummy matter is always present, which apparently coats the small crystals and prevents their growth,

The whole subject is discussed very fully in an illuminating article in a recent issue of the Agricultural Neres, one of the publications of the West Indian Department of Agriculture. It is further pointed out that during NO. 2006, VOL. 82] the past season the muscovado molasses of Antigua and Barbadoes, and to a lesser extent of other West Indian islands, has obtained a remarkably high market price, higher, indeed, than the value of the sucrose present. The chief consumers seem to have been the fishermen and lumbermen on the North American continent. There has been a simultaneous rise in the market value of the exhausted vacuum-pan molasses of Antigua. The problem of storage, therefore, assumes considerable importance; it is complicated by certain bacterial changes which are very liable to set in. But these changes are not inevitable, and with greater care in the manufacture the "souring " which so greatly reduces the market value can be to a large extent avoided. The composition of the various grades of molasses is given as follows:-

\begin{tabular}{|c|c|c|c|c|c|}
\hline & & $\begin{array}{l}\text { Muscovado } \\
\text { molasses } \\
\text { (Anifiria) } \\
\text { per cent. }\end{array}$ & & $\begin{array}{l}\text { Centrifugalled } \\
\text { first } \\
\text { molasses } \\
\text { per cent. }\end{array}$ & $\begin{array}{l}\text { Centrifugalled } \\
\text { second molasses } \\
\text { (exbausted) } \\
\text { per cent. }\end{array}$ \\
\hline & $\ldots$ & 501055 & $\ldots$ & 40 to 60 & $\ldots \quad 20$ to 40 \\
\hline luco & $\begin{array}{l}\cdots \\
\cdots\end{array}$ & $5,1=$ & $\ldots$ & $7,, 20$ & 15,40 \\
\hline Non-sugar & $\ldots$ & 3, & $\ldots$ & - & $\ldots$ \\
\hline & $\ldots$ & $3,, \quad 5$ & $\ldots$ & 3, & 10 \\
\hline r... & $\ldots$ & 24,30 & & 28 & 17,28 \\
\hline
\end{tabular}

The first molasses can be made to yield a further crop of cane sugar by re-boiling, but the second molasses cannot, and are therefore said to be exhausted.

The problem in Hawaii is very different in character. The molasses obtained there are not of the muscovado type, and consequently have no commercial value as human food. It is estimated that something like fifteen million gallons are obtained annually, of which about ten millions are used as food for stock. There is little doubt that this would be the most economical way of utilising the remainder, but unfortunately, the number of stock kept on the islands is insufficient for the purpose. Of the other twenty million gallons some is burnt as fuel, some is put on the land as fertiliser, and some is run into the sea and wasted. Decided benefit has followed the use of molasses as fertiliser in Mauritius, and there is some reason to suppose that the sugar increased the amount of nitrogen fixation in the soil; in consequence, the manurial value is higher than one would expect from a consideration merely of the amount of nitrogen and mineral matter present. These favourable results, however, are not obtained in Hawaii, and experiments have been instituted at the Experiment Station of the Hawaiian Sugar-planters' Association to find out whether molasses could profitably be converted into alcohol. Something more than 50 per cent. of sugar is present, of which 83 per cent. can be converted by fermentation into alcohol. The effect of varying conditions has been investigated and the native yeasts described.

THE AUSTRALIAN ASSOCIATION FOR THE ADVANCEMENT OF SCIENCE.

THE Australian Association for the Advancement of Science held its inaugural meeting in Sydney in September, I888, and met there again in 1898 ; in January, 1890 , it visited Melbourne, and again in 1901 ; since then sessions have been twice held at Adelaide, Hobart, and Brisbane, and once at Christchurch and once at Dunedin, in New Zealand; its next meeting will be held in Sydney in IgII.

As a rule, the meetings have been held in the capitals of the Australian States at intervals of ten years; as the inland towns like Bathurst and. Ballarat become larger and better able to provide the requisite meeting-rooms and other accommodation, they will also be visited.

One great disadvantage under which the association suffers is the very great distances which the members have to travel; the nearest meeting-places are between 500 and 600 miles apart, so that members living in Brisbane, Melbourne, and Hobart have to travel those distances to attend a meeting in Sydney, and members from South Australia and New Zealand have to travel about 1200 miles, and those from Western Australia nearly 2500 miles; when the meeting is in New Zealand all the Australian members have to undergo a sea voyage of about five days at least, and some a longer one, with perhaps some hundreds of miles of railway travelling in addition. 
People in England do not generally realise these great distances; the above towns appear to be quite close on an ordinary map, especially as the maps of Australia are usually on a much smaller scale than those of Europe and America.

It is partly on account of these great distances that the meetings are no longer held annually, but in alternate years; the yearly expenditure of time and money was too great a tax upon the working members, for, to their credit, it is they who, in spite of these disadvantages, attend the most regularly. The association has, so far, not had funds placed at its disposal to reduce the travelling and other expenses of its members (the British Association has received considerable sums for this purpose when visiting Canada and South Africa); the members, however, are granted return railway tickets for a single fare by the Government railways, and certain of the steamship companies allow a reduction of 20 per cent. off their ordinary fares. The attendance of members and associates has varied from about 600 to nearly 1200 .

The Australian Association was founded with the same aims and objects as the British Association, and its rules are very similar; the subscription is lower, viz. $r l$. for members and IOs. for associates (ladies and students) for each session, and there is no longer an entrance fee. The sessions last about a week, and the work is distributed over various sections.

Lectures to working men and others form a popular feature; also garden-parties, conversaziones, and similar social gatherings, which greatly help to bring the members together and afford opportunities to make and renew acquaintances. Local excursions to places of interest and to engineering and other works are also much appreciated, as well as the longer botanical and geological excursions.

The association does a good deal of work by means of special committees for investigation and research; money grants are made to these where necessary from the interest of the research fund (now nearly $3000 l$.), which has been slowly built up from the savings from members' subscriptions, but this has only been rendered possible by the fact that the Australian and New Zealand Governments have liberally provided for the printing of the volume of reports and proceedings. All other expenses are paid for out of the subscriptions, and the excursions are made self-supporting; no funds are provided by the towns visited for the entertainment of the members, as is done for the British Association, but private hospitality is gladly offered to visiting members.

The principal working members are naturally the scientific members of the Australasian universities, societies, museums, Government departments, and other institutions, although, as is seen from the association's publications, many others contribute valuable papers.

There is no doubt that the peripatetic meetings of the association have done much to cause many of the residents in the districts in which it has met to take an interest in scientific matters and do much for its advancement; the effect is also noticeable in the increased output of the original work of the local universities and similar institutions.

One of the greatest benefits of the meetings of the association is that it enables workers to meet and discuss matters of mutual interest, and there is no doubt that this acts as a stimulus of immensely greater value than the reading of even hundreds of pages of printed reports.

The association has one medal to award, viz. that founded in memory of the late Baron von Mueller.

The association has published eleven volumes of reports; these are of about the same size as the annual volumes of the British Association; they are well illustrated by maps, plans, and numerous reproductions of photographs. These volumes are distributed gratuitously to about 300 scientific societies and institutions throughout the world, so that they are fairly accessible to anyone interested in Australasian science, even in places so widely separated as Bucharest, Monte Video, Seoul, Port Louis, and Pietermaritzburg.

As an example of the contents of the volumes, the last report published, viz. that of the Adelaide meet ing for 1907 (the report of this year's meeting, held at Brisbane, is now being printed), may be referred NO. 2096, VOL. 82 ] to; after the list of officers, sections, committees, and other preliminary matters (thirty-two pages) there is the interesting address by the president, the late Dr. A. W. Howitt, C.M.G., upon personal reminiscences of Central Australia and the Burke and Wills' expedition, which affords a good deal of hitherto unpublished information upon this disastrous expedition; this is followed by the addresses of the presidents of the sections, beginning with Section A, for mathematics, astronomy, and physics, by E. F. J. Love, on the theory of the Voltaic cell; Section B, chemistry and metallurgy, by R. C. Stiehl, on progress in rapid oxidation processes applied to copper smelting, a most important subject in Australia ; Section C, geology, by A. Gibb Maitland, Government geologist of Western Australia, on recent advances in the knowledge of the geology of Western Australia; Section D, biology, a century of botanical endeavour in South Australia, by J. H. Maiden, Government botanist of New South Wales; Section E, geography, by Thomas Walker Fowler, upon Australasian geography; Section F, anthropology and philology, by R. Parkinson, of Ralum, Bismarck Archipelago, on totemism and its possible origin; Section G, I., social and statistical science; Section G, II., agriculture, by F. Anderson, professor of mental philosophy, Sydney University, on Liberalism and Socialism, and the outlook of agriculture in Australia, by T. Cherry, Director of Agriculture, Victoria; Section $\mathrm{H}$, engineering and architecture, no address; Section I, sanitary science and hygiene, by Dr. R. Greig-Smith, on air infection; Section J, mental science and education, by Dr. Henry Laurie, professor of mental philosophy, Melbourne University, on materialism and evolution.

Next, on p. 263 , follow the reports of committees :-

(I) For the investigation of glacial phenomena in Australasia. This contains the most recent results of the investigations into the Cambrian (?) and Permo-Carboniferous glacial history of South Australia, Victoria, Tasmania, West Australia, and New Zealand, and is supplementary to reports by this committee published in severa of the association's previous volumes. (2) For the biological and hydrographical study of the New Zealand coast. (3) On New Zealand food fishes. (4) On terrestrial magnetism in Australia and New Zealand. (5) On seismological phenomena in Australasia. This committee has worked continuously for several years, and has issued several valuable reports. (6) On a uniform system for the nomenclature of igneous rocks in Australasia.

Previous volumes contain other valuable reports from committees upon other subjects; amongst them the following may be mentioned, as they give a general idea of the matters which hav engaged, and are still engaging, the attention of the associ' ${ }^{\text {tion :- }}$

(I) Upon a uniforr system of spelling native names. (2) To inquire into and report upon the teaching of science in primary and secondary schools, technical colleges, and universities. (3) To investigate and report upon the best method of utilising diamond-drill bores for the determination of underground temperatures. Deep bores are being put down in many parts of Australia by the Governments and by private individuals for ordinary water supplies and for irrigation. (4) For collecting and cataloguing geological photographs and surveys. (5) For cataloguing marine Mollusca. (6) For cataloguing the minerals of Australia. (7) To investigate the tides of South Australia. (8) The movements of New Zealand glaciers. (9) The fertilisation of the fig in Australia. (10) On rust in wheat. (II) On Antarctic exploration. (12) On the protection of native birds and animals. (13) On improvements in museums as a means of popular education. (14) On the Adulteration of Food Acts of the Australian Governments. (15) On the chemical compositions and properties of the mineral waters of New Zealand. (I6) On the vernacular names of Australian birds.

Next follow the papers read before the sections; severa of these, in common with papers in previous volumes, are of a high order, and will be of permanent value. It would be rather difficult to make a selection of these papers, and much space would be occupied by even their titles, but it may perhaps be mentioned that in astronomy, mathematics, and physics there are eleven papers; in chemistry, \&c., ten; geology, twenty; biology, eleven; 
geography, seven; anthropology and philology, four ; social science and statistics, six; agriculture, eight; engineering and architecture, seven; sanitary science and hygiene, nine; and in mental science and education, four; this section is a very popular one with teachers and others interested in education, and the attendance is usually very large.

The association has made several recommendations to the various Australasian Governments and other authorities, and in the majority of cases these have been sympathetically received, and in certain cases carried out. One of the first recommendations was to the British. Admiralty, suggesting that the ocean between Australia, New Zealand, and Tasmania should be named the Tasman Sea; this was agreed to, and the name was at once ordered by the Admiralty to be printed on all charts; previous to this there was some difficulty in speaking of this hitherto nameless part of the Pacific.

The association has also made requests for the reservation of certain areas in Australia and New Zealand for the preservation of the native flora and fauna, some of these have been agreed to; a notable one is the reservation of the island upon which the Tuatara lizard is found. Another smaller reservation was that of a sandstone quarry at Bondi, near Sydney, showing a remarkable columnar or prismatic structure.

Amongst other recommendations made at various meetings to the Australian and New Zealand Governments are the following, some of which have been given effect to :-

(r) That the Federal Government should endeavour to obtain data in the Indian Ocean for long-distance weather forecasting.

(2) The installation at Perth, Western Australia, of a complete set of magnetographs for the continuous registration of magnetic variations; also installations at Brisbane, Port Darwin, and Hobart similar to those at Sydney, Melbourne, \&c. One has recently been installed at Adelaide in response to the association's suggestions.

(3) That the Australian and New Zealand Governments should adopt additional measures to prevent the further extension of tuberculosis amongst cattle and swine.

(4) Recommending the teaching of hygiene and the medical inspection of school children.

(5) That the New Zealand Government should undertake the magnetic survey of the Macquarie Islands now that the survey of the main islands has been completed.

(6) The Australian Governments were urged to take more effective steps for the conservation of forest areas.

The Federal Government was requested in 1902, before determining upon the site of the Federal capital, to appoint a board, consisting of architects, engineers, surveyors, medical and business men, to inquire and report upon the sites proposed; also to reserve a site for a national museum and for the housing of scientific societies and institutions in the proposed Federal capital. In $189 \mathrm{~S}$ successful recommendations were made to the New South Wales Government to proceed with the boring at Funafuti.

So that members may come prepared for the discussions, it has been agreed to arrange for the preparation of papers on subjects of which notice had been given at a previous meeting. Arrangements are being made for the preparation and publication of bibliographies which would be beyond the powers of an unaided individual.

Some of the papers of permanent value might usefully be reproduced in English publications, for in spite of the volumes of reports being widely distributed, a paper published at the Antipodes finds very few readers elsewhere because on receipt of the volumes by an institution they are usually put on the library shelves, and there they remain.

The desirability of inviting the British Association to visit Australia has been considered and warmly advocated at different times since I885; a reference to the pronosed invitation will be found on p. xxiii of the present volume, in which it was suggested at the Adelaide meeting in 1907 that a sum of ro,oool. to $20,000 l$. should be orovided to defray part of the travelling expenses of the visitors, and that the invitation should be issued for not earlier than 1913 , so as to leave plenty of time to make proper arrangements.

The permanent offices of the Australian Association are NO. 2096 , VOL. 82] in the house of the Royal Society of New South Wales, which has recently provided accommodation for other scientific societies, so as in a small way to afford some of the advantages which Burlington House provides for certain of the English societies; the Sydney societies thus housed have already found much mutual advantage from being under one roof.

A. LiverSIDGE.

\section{EPIDEMIC DISEASE AMONG THE NORTH AMERICAN INDIANS.}

$\mathrm{I}$ the Bulletin of the Johns Hopkins Hospital for November Dr. H. U. Williams discusses the origin of epidemic diseases among the North American Indians.

He believes that these American races developed an extremely small number of infectious maladies. Many of the most deadly kind-small-pox, leprosy, bubonic plague, glanders, anthrax, rabies-were the result of the introduction of infection from Europe. With regard to tuberculosis, diphtheria, influenza, gonorrhoea, beri beri, and malaria, the case is more doubtful; but these maladies do not seem to have been noticed among the native tribes by the earlier explorers. The origin of syphilis and yellow fever alone can with some degree of certainty be assigned to American soil. As contributory causes to this immunity from infection, the dispersion of the tribes in isolated camps, and the lack of domestic animals (the horse being connected with glanders, the cow with tuberculosis, and the goat with Malta fever), may have prevented the spread of disease.

Dr. Williams further attempts to identify the serious epidemic which prevailed on the western coast about $1612-20$. When the Puritans appeared on the scene they found this region almost entirely depopulated, and they regarded the epidemic as a dispensation of Providence which had removed the savages to make room for the Europeans. It seems probable that this terrible malady was introduced by foreign settlers. It is very generally supposed to have been an outbreak of small-pox or yellow fever; if this be the case, it is remarkable that the early travellers should not have described it under those names. It is significant that in $16 I_{4}$ that ruffian, Hunt, kidnapped several natives, who were carried to Europe, and after a time those who survived were brought back to their native country. Bubonic plague prevailed in London from $x 603$ to $16 \mathrm{II}$, and sporadic cases were reported in the following years. The European settlers in America seem to have escaped the disease; and if, as seems most probable, the terrible mortality among the Indians was due to plague, the settlers mav have been protected, as in the recent epidemic in India, by the fact that they were cleanlier in their habits and better shod than the native population, and that they were thus less liable to contagion through wounds or insect bites.

\section{OPTICAL ACTIVITY WITH NO ASYMMETRIC} ATOM.

$A^{N}$ important paper by Profs. Perkin, Pope and Wallach on optically active substances containing no asymmetric atom appears in the Chemical Society's Journal for November. The substance described is I-methylcyclohexylidene-4-acetic acid, and its structure is represented by the formula<smiles>CC1CCCC(=CC(=O)O)CCC1</smiles>

The carbon atom ( $\mathrm{r}$ ) is linked to two identical chains of atoms, and is therefore not asymmetric. The optical activity of the compound depends on the fact that the plane of the the $=\mathrm{C}{ }_{\mathrm{CO}_{2} \mathrm{II}}^{\mathrm{H}}$ group, the former being perpendicular to the plane of the hexagonal ring and the latter identical with it; the dissimilarity of the $-\mathrm{H}$ and $-\mathrm{CH}_{3}$ radicles 